\title{
PIJAT OKSITOSIN TERHADAP VOLUME ASI DI PMB E KOTA PALANGKA RAYA
}

\author{
Herlinadiyaningsih ${ }^{\bowtie}$, Peni Ruttata \\ Jurusan Kebidanan Poltekkes Kemenkes Palangka Raya
}

\section{ARTICLE INFO \\ Article history}

Submitted : 2021-01-04

Revised : 2021-01-07

Accepted : 2021-01-14

\section{Keywords: \\ Oxytocin massage \\ Breastmilk \\ Volume}

\section{Kata Kunci: \\ Pijat oksitosin \\ ASI \\ Volume}

\begin{abstract}
Breastmilk (ASI) is the first, main and best food for neonates, which is natural and contains various nutrients needed in the process of baby growth and development. Lack of milk production is one of the reasons why mothers give formula milk to their babies. Oxytocin massage is a massage along the spine (vertebrae) to the fifth-sixth rib and is an attempt to stimulate the hormones prolactin and oxytocin after childbirth. The purpose of this study was to determine the effect of oxytocin massage on breast milk volume. This research design is quasy experiment with post test design. The population of this study was 78 post-partum mothers with a total sample of 26 post-partum mothers who met the inclusion and exclusion criteria using purposive sampling technique. The data collection method is by pumping breast milk and measuring it using a measuring cup and observation sheet. This research was conducted in February - April 2019 at the Independent Practice of Midwives E, Palangka Raya City. Data analysis used ManWhitney. The results showed that the average value of breastfeeding volume was 21,369 in the cc intervention group and the average value of breast milk volume was $19,385 \mathrm{cc}$ in the control group. The results of statistical analysis obtained a P-value of 0.840 . The conclusion of this study is that there is no significant difference in the volume of breastmilk between oxytocin massage and oxytocin massage at the Bidan $\mathrm{E}$ Practice, Palangka Raya City. Research is needed relating to other factors that can increase the amount of milk production.

Air Susu Ibu (ASI) merupakan makanan pertama, utama dan terbaik bagi neonatus, yang bersifat alamiah dan mengandung berbagai zat gizi yang dibutuhkan dalam proses pertumbuhan dan perkembangan bayi. Kurangnya produksi ASI menjadi salah satu penyebab ibu memberikan susu formula pada bayinya. Pijat oksitosin adalah pemijatan pada sepanjang tulang belakang (vertebrae) sampai tulang costae kelima-keenam dan merupakan usaha untuk merangsang hormon prolaktin dan oksitosin setelah melahirkan. Tujuan penelitian ini untuk mengetahui pengaruh pijat oksitosin terhadap volume ASI. Desain penelitian ini quasy eksperiment dengan post test design. Populasi penelitian ini sebanyak 78 ibu nifas dengan jumlah sampel 26 ibu nifas yang memenuhi kriteria inklusi dan eksklusi dengan teknik pengambilan sampel purposive sampling. Metode pengambilan data adalah dengan cara ASI dipompa dan diukur menggunakan gelas ukur dan lembar observasi.Penelitian ini dilakukan pada bulan Februari - April 2019 di Praktik Mandiri Bidan E Kota Palangka Raya. Analisa data menggunakan ManWhitney. Hasil penelitian didapatkan nilai rata-rata volume ASI 21.369 pada kelompok intervensi cc dan nilai rata-rata volume ASI sebesar 19,385 cc pada kelompok kontrol. Hasil analisis statistik diperoleh nilai P-value 0,840. Kesimpulan dari penelitian ini yaitu tidak ada perbedaan bermakna volume air susu ibu antara pijat oksitosin dan tidak dilakukan pijat oksitosin di Praktik Mandiri Bidan E kota Palangka Raya. Diperlukan penelitian berkaitan dengan faktor lain yang dapat mempengaruhi peningkatan jumlah produksi ASI.
\end{abstract}

Corresponding Author:

Herlinadiyaningsih

Jurusan Kebidanan Poltekkes Kemenkes Palangka Raya

Telp. 082157217880

Email: herlinadiyaningsih@ rocketmail.com

\section{PENDAHULUAN}

Adanya faktor nutrien yang sesuai dalam ASI menjamin status gizi bayi baik serta kesakitan dan kematian anak menurun. Beberapa penelitian epidemiologis menyatakan bahwa ASI melindungi bayi dan anak dari penyakit infeksi misalnya diare, otitis media, dan infeksi saluran pernapasan akut bagian bawah. Kolostrum mengandung zat kekebalan 10-17 kali lebih banyak dari susu matang 
(matur). Zat kekebalan yang terdapat pada ASI antara lain akan menurunkan bayi dari penyakit diare dan menurunkan kemungkinan bayi terkena infeksi telinga, batuk, pilek, dan penyakit alergi. Dalam rangka menurunkan angka kesakitan dan kematian anak, United Nation Children Fun (UNICEF) dan World Health Organization (WHO) telah merekomendasikan bahwa sebaiknya anak hanya disusui air susu ibu (ASI) selama paling sedikit 6 bulan (Kementrian Kesehatan Republik Indonesia, 2014).

Bayi akan mengalami pertumbuhan dan perkembangan sensorik, kognitif, motorik dan sosial yang cepat. Melalui hubungan timbal balik dengan pemberi perawatan (orang tua), bayi menjalani proses tumbuh dan berkembang sesuai dengan tugas perkembangannya. Untuk mendukung proses pertumbuhan dan perkembangannya, bayi memerlukan dukungan nutrisi yang optimal (Khasanah, 2011).

Data World Health Organization (WHO) tahun 2016 masih menunjukkan ratarata angka pemberian ASI eksklusif di dunia baru berkisar 38\%. Di Indonesia meskipun sejumlah besar perempuan $(96 \%)$ menyusui anak mereka dalam kehidupan mereka, hanya $42 \%$ dari bayi yang berusia di bawah 6 bulan yang mendapatkan ASI eksklusif. Pada saat anak-anak mendekati ulang tahunnya yang ke dua, hanya 55\% yang masih diberi ASI. Jika dibandingkan dengan target WHO yang mencapai 50\%, maka angka tersebut masihlah jauh dari target. Berdasarkan data yang dikumpulkan International Baby Food Action Network, Indonesia menduduki peringkat ke tiga terbawah dari 51 negara di dunia yang mengikuti penilaian status kebijakan dan program pemberian makan bayi dan anak (Infant-Young Child Feeding). Hal Ini menunjukkan, pemberian ASI sebagai makanan pertama bayi masih kurang. Padahal, penurunan gizi anak hingga menyebabkan anak bergizi kurang hingga buruk dan tumbuh pendek (stunting) dapat dicegah sedini mungkin dengan pemberian ASI eksklusif dan MPASI yang benar.

Air Susu Ibu (ASI) merupakan makanan pertama, utama dan terbaik bagi neonatus, yang bersifat alamiah dan mengandung berbagai zat gizi yang dibutuhkan dalam proses pertumbuhan dan perkembangan bayi (Hall, 2010). Kurangnya produksi ASI menjadi salah satu penyebab ibu memberikan susu formula pada bayinya. UNICEF menegaskan bayi yang menggunakan susu formula memiliki kemungkinan meninggal dunia pada bulan pertama kelahirannya, dan kemungkinan bayi yang diberi susu formula adalah 25 kali lebih tinggi dari pada bayi yang disusui ibunya secara ekslusif (Selasi, 2009).

Hasil Survey Demografi Kesehatan Indonesia tahun 2017 memberikan gambaran kematian pada anak secara nasional, belum menunjukan hasil per Provinsi. Angka Kematian anak di Indonesia menunjukan adanya tren penurunan. Kematian neonatal turun dari 19 per 1000 kelahiran hidup menjadi 15 per 1000 kelahiran hidup, kematian bayi turun dari 32 per 1000 kelahiran hidup menjadi 24 per 1000 kelahiran hidup dan kematian balita dari 40 per 1000 kelahiran hidup menjadi 32 per 1000 kelahiran hidup. Kematian neonatal masih berkontribusi besar terhadap kematian bayi maupun kematian balita. Angka kematian neonatal merupakan salah satu target indikator SDGs dengan target penurunan menjadi 12 per 1000 kelahiran hidup dan Angka Kematian Balita 25 per 1.000 pada tahun 2030 (Kementrian Kesehatan Republik Indonesia, $\underline{2018)}$.

Pijat oksitosin adalah tindakan yang dilakukan oleh keluarga terutama adalah suami pada ibu menyusui yang berupa back massage pada punggung ibu untuk meningkatkan hormon oksitosin. Pijat oksitosin adalah pemijatan pada sepanjang tulang belakang (vertebrae) sampai tulang costae kelimakeenam dan merupakan usaha untuk merangsang hormon prolaktin dan oksitosin setelah melahirkan.

Hasil penelitian (Delima et al., 2016) menunjukkan bahwa ada pengaruh pijat oksitosin untuk meningkatkan produksi susu ibu menyusui di Puskesmas Plus Mandiangin Bukit Tinggi. Hasil penelitian (Alhadar \& Umaternate, 2017) menunjukkan bahwa ibu hamil yang melakukan perawatan payudara berpengaruh signifikan terhadap peningkatan produksi ASI diwilayah kerja Puskesmas Kota Kecamatan Kota Ternate Tengah.

Cakupan pemberian ASI Ekslusif pada bayi rata-rata di Provinsi Kalimantan Tengah pada tahun 2016 hanya mencapai $20.5 \%$ lebih rendah dibandingkan tahun 2015 yang mencapai $27.58 \%$. Cakupan pemberian ASI eksklusif di Kalimantan Tengah paling tinggi di Kabupaten Kotawaringin Barat yang mencapai 
47.8\% diikuti oleh Kabupaten Pulang Pisau $41.7 \%$ dan Kabupaten Lamandau yang mencapai $40.1 \%$. Sedangkan yang paling rendah adalah Kabupaten Murung Raya 4.4\% persen diikuti oleh Kabupaten Kotawaringin Timur 4,8\% dan Kabupaten Barito Utara sebesar 5,5\%. Beberapa hal yang menghambat pemberian ASI eksklusif diantaranya adalah rendahnya pengetahuan ibu dan keluarga lainnya mengenai manfaat ASI dan cara menyusui yang benar, kurangnya pelayanan konseling laktasi dan dukungan dari petugas kesehatan, faktor sosial budaya, kondisi yang kurang memadai bagi para ibu yang bekerja, gencarnya pemasaran susu formula (Dinas Kesehatan Provinsi Kalimantan Tengah, 2016).

Sesuai uraian tersebut, maka dilakukan penelitian yaitu pengaruh pijat oksitosin dengan breast care terhadap volume ASI di Praktik Mandiri Bidan E Kota Palangka Raya dengan tujuan untuk mengetahui pengaruh pijat oksitosin terhadap volume ASI.

\section{METODE PENELITIAN \\ Jenis Penelitian}

Penelitian ini termasuk penelitian quasi eksperiment dengan desain penelitian post test design. Penelitian ini dilakukan pada bulan Februari - April 2019 di Praktik Mandiri Bidan E Kota Palangka Raya.

\section{Populasi dan Sampel Penelitian}

Populasi penelitian ini sebanyak 78 ibu nifas dengan jumlah sampel $26 \mathrm{ibu}$ nifas yang memenuhi kriteria inklusi dan eksklusi dengan teknik pengambilan sampel purposive sampling. Responden pada penelitian ini dibagi menjadi 2 kelompok yaitu 13 ibu nifas yang diberikan perlakukan pijat oksitosin dan 13 ibu nifas yang diberikan perlakukan breast care.

\section{Pengumpulan Data}

Instrumen yang digunakan dalam penelitian ini adalah alat ukur ASI seperti Pompa ASI, gelas ukur dan lembar observasi.

\section{Analisis Data}

Analisis univariat digunakan untuk menampilkan atau melihat gambaran distribusi frekuensi responden menurut variabel yang diteliti. Pada penelitian ini analisa univariat disajikan dalam bentuk tabel distribusi frekuensi masing-masing variabel.

Analisis Bivariat digunakan untuk melihat hubungan antara variabel independen dengan variabel dependen. Pada penelitian ini untuk mengetahui pengaruh pijat oksitosin dengan breast care terhadap volume ASI, maka statistik yang digunakan adalah uji MannWhitney.

\section{HASIL PENELITIAN}

Tabel 1 didapatkan hasil sebanyak 13 responden kelompok pijat oksitosin nilai ratarata volume ASI sebesar $21.369 \mathrm{cc}$ dan nilai rata-rata kelompok yang tidak dipijat oksitosin dari 13 responden sebesar $19.385 \mathrm{cc}$.

\section{Tabel 1. Distribusi Responden Menurut Perlakuan Pijat Oksitosin dan Breast Care terhadap volume ASI di PMB E Kota Palangka Raya}

\begin{tabular}{lcccccc}
\hline \multicolumn{1}{c}{ Variabel } & Perlakuan & n & Mean & SD & Min & Mak \\
\hline Volume ASI & Pijat oksitosin & 13 & 21.369 & 18.5026 & 2.4 & 50 \\
Volume ASI & Breast Care & 13 & 19.385 & 22.9436 & 3 & 70 \\
\hline
\end{tabular}

Pada tabel 2, hasil uji statistik MannWhitney, diperoleh angka significancy 0,840 . Karena nilai $\mathrm{p}>0,05$ didapat nilai $\mathrm{p}$-value 0,840 . Maka dapat disimpulkan tidak ada perbedaan rata-rata volume ASI antara ibu nifas yang dipijat oksitosin dan yang diberikan perlakuan breast care.

Tabel 2. Perbedaan Rata-Rata Volume ASI di PMB E Kota Palangka Raya

\begin{tabular}{lccc}
\hline \multicolumn{1}{c}{ Perlakuan } & n & Rata-rata & P value \\
\hline Pijat oksitosin & 13 & 21.369 & \\
Breast care & 13 & 19.385 & 0 \\
\cline { 1 - 2 } Total & 26 & & \\
\hline
\end{tabular}




\section{PEMBAHASAN}

Hasil penelitian menunjukkan tidak ada perbedaan rata-rata volume ASI antara antara ibu nifas yang dipijat oksitosin dan yang diberikan perlakuan breast care. Hasil penelitian ini berbeda dengan hasil penelitian yang dilakukan oleh (Rahayu et al., 2015) tentang Produksi ASI Ibu dengan Intervensi Acupresure Point Lactation dan Pijet Oksitosin yang menyatakan ada perbedaan produksi ASI yang signifikan antara Acupressure Points for Lactation dan pijat oksitosin di RSUD Kabupaten Kediri.

Hasil penelitian ini pun berbeda dengan hasil penelitian yang dilakukan oleh (Delima et al., 2016) bahwa ada pengaruh pijat oksitosin untuk meningkatkan produksi susu ibu menyusui di Puskesmas Plus Mandiangin Bukittinggi. Sama halnya hasil penelitian yang dilakukan oleh (Wijayanti \& Setiyaningsih, 2017) yang menyatakan bahwa ada perbedaan antara produksi ASI ibu post partum dengan pijat oksitosin lebih lancar dibandingkan antara produksi ASI ibu post partum dengan breast care.

Dalam hal ini, pada ibu ada 2 macam refleks yang menentukan keberhasilan dalam menyusui bayinya. Refleks tersebut refleks prolaktin dan refleks aliran Refleks prolaktin refleks ini secara hormonal untuk memproduksi ASI. Waktu bayi menghisap payudara ibu, terjadi rangsangan neuro hormonal pada puting susu dan areola ibu. Rangsangan ini diteruskan ke hipofise melalui nervus vagus,turun ke lobus anterior. Dari lobus ini akan mengeluarkan hormone prolaktin, masuk ke peredaran darah dan sampai pada kelenjar-kelenjar pembuat ASI. Refleks aliran (let down refleks), refleks ini membuat memancarkan ASI keluar (Maita, 2016).

Bayi secara otomatis menghisap putting susu ibu dengan bantuan lidahnya. Let down refleks mudah sekali terganggu, misalnya pada ibu yang mengalami goncengan emosi, tekanan jiwa dan gangguan pikiran. Gangguan terhadap let down refleks mengakibatkan ASI tidak keluar (Maryunani, 2015).

\section{KESIMPULAN DAN SARAN}

Pijat oksitosin dan breast care dapat membantu ibu nifas untuk meningkatkan produksi ASInya. Bagi penelitian selanjutnya diharapkan dapat lebih meningkatkan penelitian yang berkaitan dengan produksi ASI dengan menggunakan faktor lain yang dapat mempengaruhi peningkatan jumlah produksi ASI pada ibu nifas atau ibu menyusui.

\section{DAFTAR PUSTAKA}

Alhadar, F., \& Umaternate, I. (2017). Pengaruh Perawatan Payudara Pada Ibu Hamil terhadap Peningkatan Produksi ASI di Wilayah Kerja Puskesmas Kota Kecamatan Kota Ternate Tengah Tahun 2016. Jurnal Riset Kesehatan, 6(1), 712.https://doi.org/10.31983/jrk.v6i1.2839

Delima, M., Arni, G., \& Rosya, E. (2016). Pengaruh Pijat Oksitosin Terhadap Peningkatan Produksi Asi Ibu Menyusui Di Puskesmas Plus Mandiangin. Jurnal Ipteks Terapan, 9(4), 283-293. https://doi.org/10.22216/jit.2015.v9i4.12 38.

Dinas Kesehatan Provinsi Kalimantan Tengah. (2016). Profil Kesehatan Provinsi Kalimatan Tengah.

Hall, J. (2010). Guyton and Hall Textbook of Medical Physiology (12th Ed). SaundersElsevier.

Kementrian Kesehatan Republik Indonesia. (2014). Profil Kesehatan Indonesia 2014.

Kementrian Kesehatan Republik Indonesia. (2018). Profil Kesehatan Indonesia 2017.

Khasanah. (2011). ASI atau susu formula ya?. Panduan Lengkap Seputar ASI dan Susu Formula. Flashbook.

Maita, L. (2016). Pengaruh Pijat Oksitosin terhadap Produksi ASI. Jurnal Penelitian Kesehatan Suara Forikes, VII(3), 173175. https://doi.org/10.33846/sf.v7i3.47.

Maryunani, A. (2015). Asuhan Ibu Nifas dan Asuhan Ibu Menyusui. Penerbit in media.

Rahayu, D., Santoso, B., \& Yunitasari, E. (2015). Produksi Asi Ibu dengan Intervensi Acupresure Point for Lactation dan Pijat Oksitosin. Ners, 10(1), 9-19. https://doi.org/10.20473/jn.v10i1.1852.

Selasi. (2009). Menyusui Langkah Perlindungan. Sentra Laktasi Indonesia.

Wijayanti, T., \& Setiyaningsih, A. (2017). Perbedaan Metode Pijat Oksitosin dan Breast Care dalam Meningkatkan Produksi ASI pada Ibu Post Partum. Jurnal Komunikasi Kesehatan, 8(2). http://e-journal. akbid-purworejo.ac. id/index.php/jkk15/article/view/119. 